\title{
Digital Influencer in Product Promotion: Fostering Consumers' Trust by Engaging Followers
}

\author{
F Handayani ${ }^{1}$, LW Evelina ${ }^{2}$, V Sylvina and A Lestari ${ }^{3}$ \\ ${ }^{1,2,3}$ Faculty of Economics and Communications, Universitas Bina Nusantara, Jakarta, \\ Indonesia \\ ${ }^{1}$ fitrie.handayani@binus.ac.id
}

\begin{abstract}
The fast growing users of social media has opened up a new channel for product promotions. Digital influencers are on the rise with their large follower base and their online content creation. They are regarded as as trusted tastemakers. This study observed and analysed one of the digital influencers, who is considered a beauty guru amongst her followers. Through her IG account@bylizziepara, Lizzie has built a community and relationships from her digitial content. The study aims at examining the contents of digital influencer instagram account and how she engaged with the followers. This qualitative study collected data from digital observation and interview. The result shows that the use of digital influencer for product promotions have both high tech and high touch benefit compared to advertising. However, digital influencer needs to apply the 4Cs: context, communication, collaboration and connection in their social media accounts. The study also finds that digital influencer should engage with the followers, share common values and gain trust from the followers.
\end{abstract}

Keywords: Product Promotions, Digital Influencers, Followers

\section{INTRODUCTION}

According to International Telecommunication Union [1]. the percentage of individual using internet in Indonesia is $25.37 \%$, that is a bit higher than the whole UK population. The over 67 million people with the internet in Indonesia means not only a big online market but also an amplified competition for customers' attention online.

Instagram may be the most popular social media account among millenials in Indonesia. Out of 700 millionInstagram active users, more than 45 million are from Indonesia. This figure has significantly increased from 22 million active users in 2016. According to Facebook Country Director Sri Widowati, during a press conference in Jakarta 26 July 2017, Indonesia is the biggest Instagramcommunity in Asia and Pacific.

In recent years, social media especially Instagram plays significant role in various aspect of life, including in marketing and product promotions. CEO and founder Mark Zuckerberg announced that there are more than two million advertisers in Instagram (IG) and 25 million registered business account. This shows that IG has been favorited as ideal mediafor selling $[2]$. 
In this context, the third party called Digital influencers emerged. The digital influencersare influential social media users with a large follower base. Because of their online content creation, the influencer then acts as an intermediary of the marketing communication with their audience as target group[3].

There are other terms for this phenomena, such as:key opinion leader (KOL), vlogger, micro-celebrities [4], [5], celebgram, social media influencerand, for more specific theme: Beauty Gurus, Fashion blogger/vlogger, buzzer. The similarity of those terms is the use of social media platform in building fan base/followers.

In marketing and promotional context, these Digital influencers conductelectronic wordof-mouth (eWOM) promotional functions. A statistical survey from Forbes magazine revealed that $92 \%$ of consumers believe in influencers more than traditional advertising endorses through celebrities. Thus,eWOM is far more influential since consumers believe they are receiving and sharing reliable and authentic recommendation of products and services [6]. It is fair to say that digital influencer is able to perform the function of promotion more effectively through the 'word of post'.

Digital influencers are on the rise, becoming one of the biggest marketing and public relations trends of 2017, especially those who promote lifestyle products. Amongst the products that discovered the far-reaching impact of forging alliances with digital influencers are the beauty products. The digital influencer in beauty category is also called Beauty Guru. These influencers express their passion for beauty and cosmeticsthrough make-up tutorials and product reviews in social media account.

One of the beauty gurus that have huge influence is Lizzie Parra. Lizzie Parra is on the list of the 5 (five) most popular Indonesian beauty vlogger in social media[7]. Through her IG @bylizzieparra, Lizzie -a former professional make-up artist - jumped into the world of beauty vlogger. As of mid August 2018, IG account @bylizzieparra has 157,000 followers with 3202 posts. It is quite amazing how people would trust 'a stranger' to consume a skin care or other cosmetics products. Compared to fashion, skin care and cosmetics usulaly required higher involvement to purchase. The fact is, the beauty guru is not a stranger for them because of 'special relationship' and 'engagement' made through postings, captions, comments and stories they share in social media, especially Instagram. This engagement has lead to 'trust'. Thus, trust is of utmost important to enable consumers to be more engaged in eWOM as information about products or services [6].

They appear to have higher effective than traditional advertising tactics, due to higher authenticity and credibility, which subsequently leads to lower resistance to the message. Scholars have discussed the influence of digital influencers especially in purchase intention and product decision. However, the study of their role, and how they engage audiences to promotion of a product has rarely been found. This research is expected to be a reference how digital influencers are related to the promotion context of a product.Hence the objectives of this study are 1) to analyse the contents used by influencers in promoting products and 2) to investigate how digital influencer build engagement with followers

\section{LITERATURE REVIEW}

Several related concepts are used as reference in this study, such as: social media, the digital influencers, how they could connect with audiences and how they create contents in their social media and involved in product promotions through eWOM.

Social Media. Social media, defined as "a group of Internet-based applications that build on the ideological and technological foundations of Web 2.0, and that allow the creation and 
exchange of user-generated content" [8]. This has empowered audiences to have more direction in how they consume media (on what channels) and also "archive, annotate, appropriate, and recirculate media content" and to produce Do-It-Yourself media content [9].

Social media have been defined in a variety of ways. The definition of social media as a "platform to create profiles, make explicit and traverse relationships" by Boyd \& Ellison has got more than 13,000 citations according to google scholar. A taxonomy of "social media" splitting the field into 6 distinctive categories (Blogs, Social Networking Sites, Collaboration Projects, Content Communities, Virtual Social Worlds, and Virtual Game Worlds) by Kaplan $\&$ Haenlein has more than 11,000 citations on google scholar. The trend of creating new and updating old definitions continues, as the development, use and adoption of social media are still on going [10].

Chris Heuer, the new media innovator and founder of Social Media Club discusses the Four Cs for a social operating system [11]: 1) Context: How we frame our stories. It is the use of language and other message derived from graph, color and design; 2) Communications: The practice of sharing our story as well as listening, responding, and growing. It is how we convey and share the message to others; 3) Collaboration: Working together to make things better and more efficient and effective. It is a collaboration between sender and receiver, in this case we could also include collaboration between social media accounts so the message could be well and broadly delivered; and 4) Connections: The relationships we forge and maintain. How we build a sustainable relationship? It is how social media users utilize all features to stay connected.

Digital Influencer. Digital influence is the ability to influence, change opinions and behavior online, generally through social networking. Simply put, digital influencers are those who have a great influence on social media. These influential individuals already gain trust from their online peers, and their opinions can have a tremendous impact on online reputation, including for products / brands [12].

Digital influencer can be scrutinized from three aspects: Reach, Resonance and Relevance. If a digital influencer makes a post on social media, how many followers 'engage' with by giving 'like', 'share', retweet ', comment, click on links or URLs of ads, or further actions such as filling out forms or making a purchases. This engagement can occur if the digital influencers consistently build communication with followers and have the image/reputation that matches or can be associated with the product offered.

It is related to the social effect theory, where reach and resonance are defined by a series of gauges, measurements, and scales governed by the study of the elements and conditions that contribute to the ability to disrupt ordistract activity in your favor [11].

Instagram. Digital influencer being discussed in this study is Lizzi Parra, from her Instagram account @bylizzieparra has influenced her followers about style and beauty. Instagram application was first created in 2011, developed by Kevin Systrom and Mike Krieger fromBurbn, Inc. It is one of the most popular social networking sites and currently has over 500 million active users and counting [13]Instagram is currently under Facebook, Inc.

Instagram is a social networking site that provides users with video and photo sharing possibilities. It has several features that support its users to interact and engage in this platforms. The features are, as follows [13].

1. Homepage : The main page displaying the timeline of recent photos of fellow users that have been followed.

2. Comment : As a social networking service, a comment feature is required. Every post in Instagram can be commented by text or by emoticons. 
3. Explore : The display of the most liked photos, similar with the trending topics in Twitter.

4. News feed : This feature displays notifications of various activities performed by Instagram users. News feeds have two types of tabs namely "following" and "you":

5. Follow : menu 'Find friends' in the 'Settings' page provides several alternative search channels. There are five channels provided: From My Contact List, Facebook friends, Twitter friends, search names and usernames and suggested friends. Follow the names you selected. All five can be used to improve search results.

6. Sharing : Instagram gives users the ease to share their photos to other popular settings social networks. Currently there are five social networks that are supported ie twitter, facebook, flickr, tumblr and foursquare.

7. Filter : Instagram provides multiple filter that allows users to enhance photos.

8. Hashta : A label (tag) is a word prefixed with a symbol marked by (\#). It makes it easy for users to find photos in Instagram with certain labels.

9. Location: : All smart phones are now equipped with geotagging features. Instagram maximizes this technology by providing location features. So each photo with the uploaded geotag feature will show the location where it was captured.

10. Like: : You give 'like' in the photos in timeline. The 'like' sign indicates how popular the photo.

11. Mentions: : Mentions can be applied both in captions and comments.

12. Insta story : It's a report to friends, and a statement of someone's style.

Promotion. According to Tjiptono [14] promotion is a form of marketing communication with the purpose to disseminate information, to influence/ persuade or to remind the target market about the company and its products, in order to accept, buy and become loyal to the products offered. There are three basic objectives of promotion. These are: to present information to consumers, to increase demand, and to differentiate a product.

\section{MATERIAL AND METHODS}

This is a qualitative research uses case study method to get detailed description and comprehensive role of Digital Influencer in product promotion. Case study was chosen because the Digital Influencer phenomenon is a case of "specific and contextual" [15] especially in the beauty industry. The second method employed was content analysis to examine how social media influencers engage with their followers as well as the techniques that they appear to use to promote some product. In order to conduct this qualitative content analysis, the author analyzed instagram posts based on four Cs characteristics in social media: context, communications, collaboration and connection.

The object of this research is Lizzie Parra instagram account: @bylizzieparra.Data were collected by observing instagram account @bylizzieparra during January-March 2018 period and conducting interviews with two digital agencies, namely Kayu Api DigitalReputation and Studio One Butiq Agency. Once all data were gathered, the data analysis was conducted through data reduction. In order to develop a comprehensve understanding of phenomena, method and investigator triangulation were employed. 


\section{RESULT AND DISCUSSIONS}

Lizzie Parra specifically shows her enthusiasm about make-up and beauty through her Instagram account@bylizzieparra. Having a background as a professional MUA (make-up artist), Lizzie posseses capacity to share her opinion about beauty.

In terms of four Cs in social media, a concept coined by Chris Heur, the digital observation from this account showed:

- Context. As a photo and video sharing application, Lizzie shared her interest and daily activities photos and video through Instagram. The photos are generally close-ups, using high key and good shooting technique, and have 'professional' look. The use of high key photo givesa modern clean edgy impression. The captionpresented in casual manner, as if a conversation between good friends. In general, Lizzie's timeline is neat and attractive

- Communications. It is about how Lizzie conveyed a message that makes people hear, respond, and share the message to bigger audience. Lizzie often shared tips about how to apply make-ups and how to choose colors that are suitable for various skin colors, for examples. As a professional make-up artist, Lizzie posseses expertise and capacity tothe beauty subject. That makes her a credible source for that matter. This is in accordance with a concept by Gladwell [16] that mavens/influencers are not only about the size of followers, but also their expertise and credibility on certain subjects.Lizzie uses conversational tones, or sometimes in the form of questions, that makes her posts interactive.

- Collaboration. It potrays the cooperation between influencer with followers to ensure the messages conveyed effectively and efficiently. In this case @bylizzieparra occasionally responded to comments from the followers. For example when one follower asked why upon applying BLP Beauty, the lipstick clumped after a short while. She responded and gave advice to use moisturizer before applying lipstick from BLP for best result. The interaction shows the good cooperation between the influencer and the follower, which certainly gives a very good impression to his followers that Lizzie is cooperative enough to help her followers. More over, that example is also a showcase of how influencer ensures the message/image of the product she reviewed/recommended. Something that could not be done by traditional advertising endorser.

- Connectionis how to build a sustainable relationship. In one of her post, @ bylizzieparraasked "What makes you smile today?". She then got hundreds of responses from her followers who answered the things that make them smile. The communication that Lizzie built made the followersfelt emotionally connected, because what made Lizzie smile was a simple thing that they could experience as well. Activities that Lizzie did on her IG accountcould be considered as investment for sustaining relationships. By giving a response from followers' comment, Lizzie made them feel heard and respected. Another example is when Lizzie gave a kind of teaser about her future activities. She spread her excitement and made her followers curious. She invited followers to take part of her activities.

People learn from example, and influencers lead by example for those who "follow" them. By observing examples through social media, people are more likely to adopt the behaviors 
exhibited by the influencer [17]. Digital influencer like Lizzie Parra could influence her followers by using certain products ('the example') on her instagram account.

The purpose of utilizing Lizzie to be a 'spoke person' of a brand or company is to establish dialog as well as build relationship with consumers. Influencers like Lizzie, have direct access to specific consumers, the followers. The means by which firms attempt to inform, persuade, and remindconsumers - directly or indirectly-about the products and brands they sell are called marketing communication[16]. In a sense, digital influencersare marketingcommunications tool that represent the voice of the company and its brands; they are a means by which thefirm can establish a dialogue and build relationships with consumers.

In relation to that, to identify and select these so-called influencers who may have a strong impact on their target audience and influence them to try and adopt new products and help diffuse them in their social network through their posts is the major challenge for the company [18].

The number of followers, which reflects network size and serves as an indication for popularity, is frequently used to identify these influential nodes. However, with the development of digital technology and the advancement of user generated content, the size of the followers could no longer be the sole criteria. According to our informant, Priska-a digital practitioner from Studio One Agency, said that the number of followerscould indicate a good quality content. Even so, company should also observe the timeline to check whether the photos previously posted are in line with the brand value. Another consideration is the engagement occured in each postings. Good influencers posses good contents that invite many comments and trigger discussions. One of informal indicators of engagement from a digital influencer is to have 'likes' from at least $20 \%$ of the total followers from each posting.

The similar ideas were also mentioned by other informant Riska, Manager Social Enggagement\& Community fromKayuApi Digital, a digital agency. Digital Influencer in Instagram is considered by two things: quantity and quality aspects. The quantity aspect is clearly shown by the number of followers, the number of 'likes' and the number of 'repost'. The quality aspect is considered by the contents and engagement. Engagement is the interaction that occurs among the instagam users. Engagement can be analysed such as by the comments and respond toward post.

IG account@bylizzieparra is considered suitable to be a digital influencer because of Lizzie's consistency about health and beauty issue since she became a beauty blogger. The followers of her Instagram are mostly the followersfrom her previous blog. It indicates that the followers are loyal follower, not a machine-generated followers. We also interviewed Wina, one of Lizzie's followers who has followed Lizzie's tips and tutorials from her blog, and now is also a follower of @bylizzieparra. Wina said that Lizzie always portray a fun and down-toearth personalities and relatable impression on her followers. Products reviewed/endorsed by Lizzie are relatively affordable and useful to support the beauty. The contents of her posts match her expertise, as well as her fun and exciting lifestyle. So when Lizzie gives a review/endorse about a product, it is like giving advice / tips to friends, not just promoting or paid-promo.

The ability to influence 'like a friend' is the quality sought after from a digital influencer. This quality distinguishes digital influencer from conventional advertising. Digital influencer is the real example of integration of PR (credibility, word of mouth) and marketing(promotion, marketing communication). The role of digital influencers in product promotion is considered more efective and efficient, as resulted from a survey from McKinsey. According to a McKinsey Study, marketing-inspired word-of-mouth generates more than twice the sales of paid advertising, and these customers have a 37\% higher retention rate [19]. 
Digital influencers are on a rise. It becomes one of the most wanted profession among milenials. The huge revenues and fun flexible work has tempted many people. According to Riska, a digital influencer could be paid 10-15 million rupiah for 2 postings about a product. This price varies depending on what kind of Insta features that will be used, the size of the followers, the quality of influencers (engagement values). A photo endorsement through Insta Story averagely costs 6 million rupiah, while video endorsement could cost 25-30 miliion rupiah.

The benefits of promoting through digital influencers in Instagram are related to features of Instagram, such as tag, hashtag, link, and regram. All promotion through digital influencer will tag the company official account and use certain hashtag. The use of the company official account and hashtag give the followers opportunities to connect with the brand directly with a simple click. Hashtag facilities make it easier to search a post/topic. Tag feature makes it possible to 'invite'or 'inform' friends, or forward the product to specific people. For example on one of Lizzie's posts about facial cleanser, followermade a comment by tagging her friends to try the product.

Based on the above explanation, promoting products by utilizing digital influencers is an important consideration in promotional activities in this digital era, especially for products that have a target audience of millenial generation, since they are highly engaged with digital media.

\section{CONCLUSIONS}

Based on the above explanation, promoting products by utilizing digital influencers is an important consideration in promotional activities in this digital era, especially for products that have a target audience of millenial generation, which is very engaged with digital media.

The study showed that in order to get instant effect on product recognition can be obtained by using digital influencers. Digital Influencer can quickly disseminate promotional messages of a product in social media like Instagram. The digital influencer has a high credibility, therefore can foster trust in the product being promoted.

The speed of spreading the message and how the message easily becomes viral are the main advantages of communication in this digital age. Instagram has features that support the rapid dissemination of information, as well as reaching target audiences. Unlikea massive but general conventional advertising, promotion through influencers is more targeted because company could check inluencer profiles and followers to match it with company's target audience. So the promotion through the digital influencer in Instagram could reach specific and targeted audiences.

Another thing that makes digital influencer becomes more influential is because of its high tech and high touch quality. High tech refers to technology that supports digital communication. High touch is an emotional and relational thatoccur between influencers and followers. The better engagement that the influencers built with the followers, the better relationships and the higher trust created from this interaction. A value that could not be obtained from conventional advertising model.

From the above discussion, it can be inferred that for the promotional purposes, there are criteria in choosing a digital influencer. The 'trust' factor is considered one of the important criteria. The trust factor is something an influencer could not build instantly. It gains from their values, consistency and engagement with their followers. It can be analysed by the four Cs they have done in their social media account. 
Lizzie Parra is an ideal example of a digital influencer. Not only she has large number of followers, but also she has built the context, communication, collaboration and connection on her IG account@bylizzieparra. Lizzie also keeps the balance contents on her account, share her daily activities and lifestyle and not merely endorsement or product promotion. This makes her account seems not too commercial. It is important to maintain followers' trust.

For consumers, getting information from a trusted source, such as@bylizzieparra, allows consumers to feel as if they are making a more informed decision when making a purchase of a product.

\section{ACKNOWLEDGEMENT}

The authorsare thankful to Bina Nusantara University, especially the Faculty of Economy and Communication, for supporting the authors to complete this article.

The authors thank the informants from this research: 1) RiskaNoerZaitun, Manager Social Enggagement\& Community KayuApi Digital; 2) Priska, Manager Digital PR Studio One; 3) Wina Melissa, a beauty enthusiast, follower @bylizzieparra, for the valuable information given to shape this article.

\section{REFERENCES}

[1] International Telecommunications Union, "Percentage of Individuals Using Internet," International Telecommunications Union, 2017. [Online]. Available: https://www.itu.int/en/ITU-

D/Statistics/Documents/statistics/2016/Individuals_Internet_2000-2015.xls.

[2] J. Yordan, "Instragram Kini Dipakai 25 Juta Pelaku Bisnis untuk Jualan,” 2018. .

[3] S. Liu, C. Jiang, Z. Lin, Y. Ding, R. Duan, and Z. Xu, "Identifying effective influencers based on trust for electronic word-of-mouth marketing: A domain-aware approach," Inf. Sci. (Ny)., vol. 306, pp. 34-52, Jun. 2015.

[4] T. Senft, Camgirls: Celebrity and Community in the Age of Social Networks Digital Formations. New York: Peter Lang, 2008.

[5] A. Marwick, Status update: celebrity, publicity, and branding. New Haven: Yale University Press, 2013.

[6] H. Hashim and M. F. Ariffin, "Factors Influencing Electronic Word of Mouth (eWOM) Engagement on Social Networking Sites in Malaysia Pertanika," J. Soc. Sci. Humanit., vol. 24, p. 86, 2016.

[7] Valentia, "Inilah 5 Beauty Blogger Indonesia Paling Terkenal,” 2017.

[8] A. M. Kaplan and M. Haenlein, "Users of the world, unite! The challenges and opportunities of Social Media," Bus. Horiz., vol. 53, no. 1, pp. 59-68, Jan. 2010.

[9] R. Nasrullah, Media Sosial; Persfektif Komunikasi, Budaya, dan Sosioteknologi. Bandung: Simbiosa Rekatama Media, 2015.

[10] S. Wolf, M and Y. H, "Social Media? What Social Media?," in ECIS 2015, 2015.

[11] B. Solis, "Engage!The Complete Guide for Brands and Business to Build, Cultivate, and Measure Success in the New Web," Wiley \& Sons, New Jersey, 2010.

[12] D. Ryan and C. Jones, "Understanding Digital Marketing. Marketing Strategies For Engagging the digital generation.” Kogan Page, London, 2009.

[13] B. D. Atmoko, Instagram Handbook. Jakarta: Mediakita, 2012. 
[14] F. Tjiptono and D. Anastasia, Prinsip \& Dinamika Pemasaran. Yogyakarta: J\&J learning, 2002.

[15] R. Kriyantono, Teknik Praktis Riset Komunikasi. Jakarta: Kencana Prenada Media Group, 2008.

[16] P. Kotler and K. L. Keller, Marketing Management. New Jersey: Prentice Hall, 2012.

[17] K. Forbes, "Examining the Beauty Industry's Use of Social Influencer sElon Journal of Undergraduate Research in Communications," Elon J. Undergrad. Res. Commun., vol. 7, no. 2, pp. 78-87, 2016.

[18] L. Pophal, "Influence Marketer: Turning Taste Makers into Your Best Sales people," 2016.

[19] K. Wong, "The Explosive Growth Of Influencer Marketing And What It Means For You," 2014. . 